\title{
Drivers of entrepreneurial intention among economics students in Indonesia
}

\author{
Ludi Wishnu Wardana, Bagus Shandy Narmaditya, Agus Wibowo, Fitriana, \\ Thusy Tiara Saraswati, Riza Indriani
}

\begin{abstract}
A B S T R A C T
Objective: The objective of the article is to investigate the impact factors on entrepreneurial intention among economics students in Indonesia. It examines how culture, attitude, and entrepreneurship education affect students' entrepreneurial intention.

Research Design \& Methods: The study applied a quantitative method using structural equation modelling. A questionnaire survey was done using a sample of 376 economics students in Malang of East Java, Indonesia.

Findings: The findings confirmed that entrepreneurial culture and attitude have successfully affected students' intention of being entrepreneurs. The results of this study indicated the essential role of entrepreneurial attitude in mediating the relationship between entrepreneurial culture, entrepreneurial education, and intention to become an entrepreneur.

Implications \& Recommendations: These findings suggest several actions for both universities and the Indonesian government to elaborate the entrepreneurship education model, which applied more practical experience instead of classroom theories.

Contribution \& Value Added: The study further elaborated the scholarly understanding of driving factors of students' intention to become entrepreneurs.

$\begin{array}{ll}\text { Article type: } & \text { research article } \\ \text { Keywords: } & \begin{array}{l}\text { entrepreneurship education; entrepreneurial intention; entrepreneurial attitude; entre- } \\ \text { preneurial culture; students' intention }\end{array} \\ \text { JEL codes: } & \text { A20, D91, L26 }\end{array}$
\end{abstract}

Received: 5 April $2020 \quad$ Revised: 30 October $2020 \quad$ Accepted: 6 November 2020

\section{Suggested citation:}

Wardana, L.W., Narmaditya, B.S., Wibowo, A., Fitriana., Saraswati, T.T., \& Indriani, R. (2021). Drivers of entrepreneurial attitude among economics students in Indonesia. Entrepreneurial Business and Economics Review, 9(1), 61-74. https://doi.org/10.15678/EBER.2021.090104

\section{INTRODUCTION}

In the recent few decades, awareness has grown about the role of entrepreneurship. For instance, the types entrepreneurship career have remained a trend in current research (Pruett et al., 2008; Zamrudi \& Yulianti, 2020). Some scholars consider a model of entrepreneurial determination that identifies several factors shaping decisions in entrepreneurship (Schlaegel \& Koenig, 2014; Diegoli et al., 2018; Şeşen \& Pruett, 2014; Zampetakis et al., 2011). The reason for the increasing attention of scholars is the essential role of entrepreneurship in job creation, poverty alleviation, and the economic growth of nations (Engle et al., 2010; Zampetakis et al., 2008; Udayanan, 2019).

Indonesia faces a big challenge of reducing poverty and unemployment rate (Nagib \& Ngadi, 2008). To deal with that issue, the Indonesian government in collaboration with universities provides a program to enhance knowledge, skill, and attitude towards entrepreneurship based on technology and information. The program was intended to change students' mindset toward becoming entrepreneurs, which should create new job opportunities and lower the unemployment rate. Hence, entrepreneurial 
intention is crucial for an individual and must be continuously presented to the students (Syuhada \& Gambett, 2013; Wibowo et al., 2018).

A prior study by Cheng et al. (2009) reveals that students who experienced developing various technical skills and training are more confident to become entrepreneurs. Unfortunately, the finding shows an insignificant relationship between entrepreneurial knowledge and interest in starting a business due to ineffective entrepreneurial learning methods used. Entrepreneurial attitude is an agent of change that leads productivity and profitability (Borasi \& Finnigan, 2010). Attitude is a tendency to like or dislike objects, people, institutions, and events (Küttim et al., 2014); it is evaluative, that is related to someone's evaluation of an object. If the object is considered to be beneficial, then someone will be supportive, and vice versa.

On the other hand, Hofstede (2001) underlines culture as an embodied mind programming that differentiates elements of one group from other groups. Hayton and Cacciotti (2013) define concepts as expected values, beliefs, and behaviours that are quite common among people in certain geographical areas. Moreover, some scholars argue that the cultural sense will drive uncertainty tolerance and risk-taking, as these are forecasted to support creativity and innovation that underlie entrepreneurial action (Kreiser et al., 2010). The findings of Zahra and George (2002) confirm that entrepreneurial action is incorporated either by beliefs or values shared culturally that support or hinder the required behaviour. Similarly, Karayiannis (1993) mentions that entrepreneurs form their beliefs through cultural heritage and direct life experience. This implies that entrepreneurial culture impacts entrepreneur education conditioning (Şeşen \& Pruett, 2014; Adekiya \& Ibrahim, 2016).

Culture influences values, attitudes, and beliefs (Adekiya \& Ibrahim, 2016). Some literature continues to develop this thread by arguing that culture is one of the crucial factors of a country's economic level (Porter, 1990) and the development of entrepreneurship (House et al., 2002). Hence, national culture is linked with the level of entrepreneurship either through cultural benefit that is part of a community (Triandis, 1982) or through an organization that represents that culture (Ahlstrom \& Bruton, 2002; Dickson et al., 2004). Expanding this reason motivates the proposition that the higher the density of entrepreneurial orientation among a country's residents, the larger the presence of possible entrepreneurs and the higher the level of new business generation (Mueller \& Thomas, 2001).

Besides entrepreneurial studies, what also recently gained importance is the study of causality between entrepreneurial culture and entrepreneurial intention. For instance, Ao and Liu (2014) and Şeşen and Pruett (2014) state that entrepreneurship culture influences entrepreneurial intention. Their findings show that culture is essential in every dimension of entrepreneurship because it determines individual attitudes towards entrepreneurship initiation. Despite the growing interest in whether entrepreneurial culture impacts entrepreneurial intention, researchers overlook how culture impacts entrepreneurial behaviour (Hayton et al., 2002; Zahra et al., 1999). Most studies ignore testing the effect of variable entrepreneurial attitude, entrepreneurial intention, and the mediating role of entrepreneurial attitude and entrepreneurial education.

The contribution of this article is twofold. First, this study overviews current literature in entrepreneurship studies from the perspective of culture and attitude. A preliminary study by Matlay et al. (2012) introduced the term of 'culture' as 'shared believes and attitudes.' In this study, we provide a different indicator and meaning of culture that brings different knowledge. Moreover, we elaborated entrepreneurial attitude that is missing in previous studies. Secondly, Indonesia has a unique culture, which is well known as a mutual cooperation (gotong royong) society. Since this finding shows a correlation between culture, intention, and attitude, it elaborates the cultural values for increasing entrepreneurs in Indonesia. The study on entrepreneurship in Indonesia is crucial due to the lack number of entrepreneurs compared to the rest of population. Indonesia ranks 94 th in the level of entrepreneurs compared to other countries such as Singapore (27th), Brunei (53rd), and Malaysia (58th) (Acs et al., 2017).

The article is divided into five sections. The introduction section is followed by the literature review, which highlights the addressed research gap in the context of Indonesia. The next section concerns methodology. The fourth section involves findings and statistical calculations, followed by conclusions that cover the implications, limitations, and recommendations of the study. 


\section{LITERATURE REVIEW}

Entrepreneurial intention is closely linked to the theory of planned behaviour (TPB) introduced by Ajzen (1991). The TPB is a development and refinement of the reason action theory (TRA) proposed by Fishbein and Ajzen (1975). These two theories have share the focus on individual's intention to present a behaviour. Based on the TPB and TRA, intention can be applied to understand and predict the factors that affect individual behaviours. Entrepreneurial intention involves the cognitive process of the behaviour applied by an individual either to establish a new business or to produce new value in a company (Fini et al., 2012; Karimi et al., 2016). Emrah et al. (2013), Ibrahim and Mas'ud (2016), and Jena (2020) note that there are three factors affecting entrepreneurial intention, which are personality, the environment, and demography. Personal characteristics include traits and backgrounds, while environmental factors include entrepreneurship education as a determinant of entrepreneurial intentions.

Entrepreneurship education links teaching and learning about entrepreneurship, which seek to enhance the personal knowledge, skills, attitudes, and character of students according to their age and capabilities (Ayalew \& Zeleke, 2018; Oosterbeek et al., 2010; Solesvik et al., 2014; Gerba, 2012). Moreover, Bergmann et al. (2018), Wach and Wojciechowski (2016), and Kirkwood et al. (2014) note that the factors influencing students' entrepreneurial intentions are belief in the current condition and prospects for entrepreneurship in the future. Generally, entrepreneurship education is intended to reinforce students' recognition of entrepreneurship as a career opportunity and foster their understanding of inaugurating and managing new business (Linan et al., 2017). However, Kusmintarti et al. (2014) indicate that entrepreneurship education insignificantly affects entrepreneurial attitude when emphasis lies solely on the theoretical aspects.

Besides entrepreneurial education, the entrepreneurship concept results from the influence of individual circumstances in local context or culture (Reynolds et al., 2007; Kibler, 2013). Hofstede (2001) and Collins et al. (2004) assert that culture is concerned with the suffusive organizing of the mind that differentiates members of one group from members of another. Culture is a feature that can promote career opportunities decisions (lakovleva \& Solesvik, 2013), and provide or hinder company establishment (Kreiser et al., 2010; Akcay et al., 2014; Ao \& Liu, 2014; Vargas-Hernández et al., 2010). Previous studies by Ao and Liu (2014) and Şeşen and Pruett (2014) reveal that entrepreneurial culture affects entrepreneurial intention. However, those studies did not find the influence of entrepreneurial education on entrepreneurial culture.

Several theoretical approaches and empirical evidence show that attitude cannot occur when considered as a one-dimensional construction, because its evaluation contains two inseparable components, one being instrumental or cognitive and the other being experiential or affective (Botsaris \& Vamvaka, 2016). The instrumental element refers to considerations that are more cognitive instead of a behaviour that seeks something beneficial and in accordance with thoughts, knowledge, and perceptions. The affective component refers to emotions, feelings (e.g. excitement, satisfaction), and impulses generated by chances of individual behaviour (Ajzen, 1991; Botsaris \& Vamvaka, 2016; Fayolle \& Gailly, 2015; Yan, 2014).

Scholars long debated that cognition has a reciprocal influence in shaping instrumental and affective attitudes as causal to each other (Fernandes \& Proença, 2014). Longitudinal data are required to initiate a causal correlation between these two elements of attitude. Wach and Wojciechowski (2016) indicated that there is a robust connection between entrepreneurial attitude and the intention to become an entrepreneur. Taormina (2019) states that attitudes and environments may influence entrepreneurial intentions. Measured by psychological characteristics, attitudes have a substantial effect on entrepreneurial potential. At the same time, the environmental factor - which includes social, economic, political, and infrastructure development - has a strong influence on entrepreneurial success. Intention remains the crucial and unbiased predictor of career options (Hackett, 2018; Sajjad \& Dad, 2010; Miranda et al., 2017). Previous research results state that entrepreneurial attitudes have a significant and robust consequence for entrepreneurial intentions (Guerrero et al., 2008; Hsu et al., 2016; Hussain \& Norashidah, 2015; Liñán, 2008). The above findings allow us to assume the following research hypotheses: 
H1: Entrepreneurial culture positively influences entrepreneurship education.

H2: Entrepreneurial culture positively influences entrepreneurial attitude.

H3: Entrepreneurial education positively influences entrepreneurial attitude.

H4: Entrepreneurial attitude positively influences entrepreneurial intention.

H5: Entrepreneurial culture positively influences entrepreneurial intention.

H6: Entrepreneurial attitude mediates the impact of entrepreneurial culture and entrepreneurial intention.

H7: Entrepreneurial attitude mediates the impact of entrepreneurship education and entrepreneurial intention.

\section{RESEARCH METHODOLOGY}

\section{Research Methods}

This study applied a quantitative method using structural equation modelling to comprehensively understand the relationship among variables. The study involved a cross-sectional survey of economics faculties from several universities in Malang of East Java, Indonesia. To attain the objectives, this study develops a structured online questionnaire. This study engaged several variables, including the intention to become an entrepreneur, entrepreneurship education, culture, and entrepreneurial attitude. The framework of the research is provided in Figure 1.

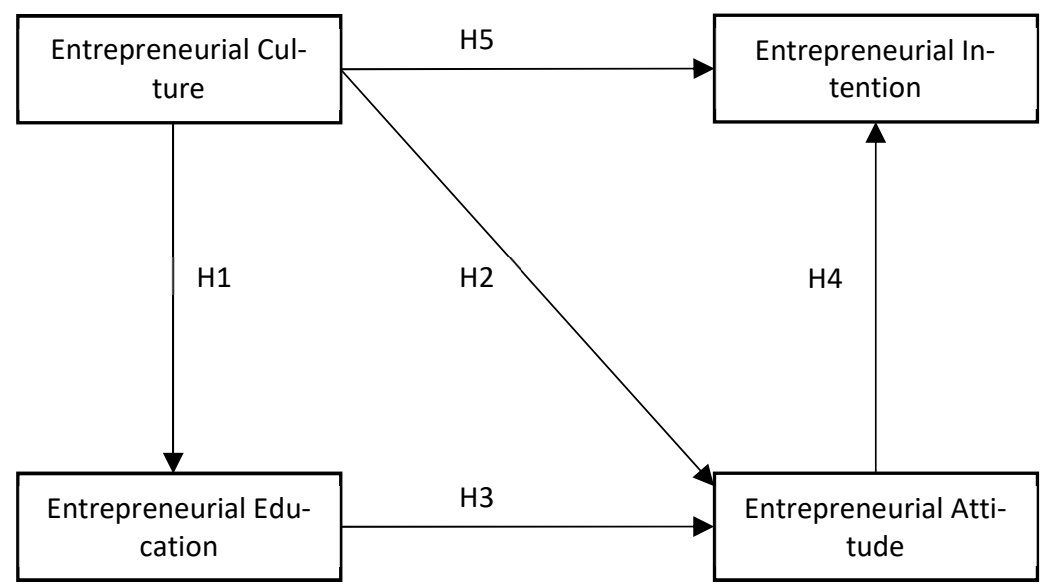

Figure 1. The theoretical framework methodology

Source: adapted from Krueger et al. (2000); Linan \& Chen (2009); Mathisen \& Arnulf (2013); Ackenzie et al. (2011); Ireland et al. (2009); Denanyoh et al. (2015).

\section{Population and Sample}

An online questionnaire was used to gather information from volunteers from September to December 2019. The sample in this study was determined through a convenience sampling technique following Sekaran and Bougie (2009) and Malhotra (2010). The total of 425 questionnaires were provided online, and approximately 373 were usable in the following analysis. The response rate of $88.47 \%$ was relatively high. The rationale for using economic faculty students as respondents was that they received entrepreneurship education and conducted various entrepreneurial training and practices organized by universities, ministries of higher education, and SMEs in collaboration with universities. The respondents demographic in this study consisted of 127 men $(33.77 \%)$ and 246 women $(65.42 \%)$ The study was conducted among first-year, second-year, and third-year undergraduate students and students in the final year of their graduate studies. In more detail, class 2014 numbered two students (0.53\%); class of $2015-5$ (1.34\%); class of $2016-98$ (26.06\%); class of $2017-249$ (66.22\%); class of $2018-10$ (2.66\%); class of 2019 - nine (2.39\%). 


\section{Research Instruments}

All the construct's calculation was adapted from preliminary works with a slight modification for the Indonesian context. The questionnaire included 35 questions framing each participant's profile and variables to be examined. The seven-items questionnaire was adapted from Krueger et al. (2000) and Liñán and Chen (2009) to measure entrepreneurial intention, while another seven-items questionnaire was expanded from Mathisen and Arnulf (2013) to understand the entrepreneurial mindset. Moreover, to measure the entrepreneurial culture, we adapted 10 indicators from Mackenzie et al. (2011) and Ireland et al. (2009), while to measure entrepreneurial attitude, we adapted five indicators from Linan and Chen (2009). Finally, to calculate entrepreneurship education, the authors engaged six indicators from Denanyoh et al. (2015). A five-point Likert scale was employed for each variable from 1 for 'strongly disagree' to 5 for 'strongly agree.'

\section{RESULTS AND DISCUSSION}

In the initial stage, we tested an exploratory factor analysis using SPSS to validate data, evaluate dimensions, preserve firm indicators (Allen \& Bennett, 2010), and pursue a reliability test with the criteria of Cronbach's alpha of 0.6 or higher (Hair et al., 1998). The second stage was the confirmatory factor analysis with AMOS 25 . To obtain the fitting model, it had to satisfy certain criteria and cut-off values, namely $p>0.5$ (Schermelleh-Engel et al., 2003), CMIN / DF of < 2 (Tabachnick \& Fidell, 2007), and RMSEA of $\leq 0.06$ (Hu \& Bentler, 1999).

\section{Exploratory Factor Analysis}

According to the calculation of exploratory factor analysis, there generally are 38 factors that consist of Entrepreneurial Intention (6), Entrepreneurial Attitude (5), Entrepreneurial Culture (19), and Entrepreneurial Education (6). All factors have Cronbach's alphas ranging from 0.599 to 0.975 , and they are considered reliable for inclusion in further analysis.

\section{Hypotheses Testing}

According to Structural Equation Modeling (SEM) analysis, a fitting model was obtained with a probability score of 0.069, a CMIN / DF score of 1.270, a CFI score of 0.995, and an RMSEA score of 0.027. As presented in Tables 1, H1, H2, H3, H4, and $\mathrm{H} 5$ were significant with CR scores of 17.937, 2.823, 2.161, 11.586, 3.584, respectively. Furthermore, $\mathrm{H} 6$ and $\mathrm{H} 7$ also satisfied the criteria with CR scores of 2.124 and 2.742 (see Table 1 and Figure 2).

Table 1. Result summary of theoretical framework testing

\begin{tabular}{|l|l|c|c|c|}
\hline \multicolumn{1}{|c|}{ Hypotheses } & \multicolumn{1}{c|}{ Impact } & CR & P & Decision \\
\hline $\mathrm{H} 1$ & $\mathrm{EC} \rightarrow \mathrm{EE}$ & 17.937 & 0.000 & Accepted \\
\hline $\mathrm{H} 2$ & $\mathrm{EE} \rightarrow \mathrm{EA}$ & 2.823 & 0.005 & Accepted \\
\hline $\mathrm{H} 3$ & $\mathrm{EC} \rightarrow \mathrm{EA}$ & 2.161 & 0.031 & Accepted \\
\hline $\mathrm{H} 4$ & $\mathrm{EA} \rightarrow \mathrm{EI}$ & 11.586 & 0.000 & Accepted \\
\hline $\mathrm{H} 5$ & $\mathrm{EC} \rightarrow \mathrm{EI}$ & 3.584 & 0.000 & Accepted \\
\hline $\mathrm{H} 6$ & $\mathrm{EC} \rightarrow \mathrm{EA} \rightarrow \mathrm{EI}$ & 2.124 & 0.006 & Accepted \\
\hline $\mathrm{H} 7$ & $\mathrm{EE} \rightarrow \mathrm{EA} \rightarrow \mathrm{EI}$ & 2.742 & 0.006 & Accepted \\
\hline
\end{tabular}

Note: $\mathrm{EC}=$ entrepreneurial culture; $\mathrm{EE}$ = entrepreneurial Education; $\mathrm{EA}$ = entrepreneurial Attitude; $\mathrm{EI}$ = entrepreneurial intention. Source: own study.

\section{The Relationship Between Variables}

The results of this work address the seven proposed hypotheses. The first hypothesis (H1) shows that there is a positive impact of entrepreneurial culture on entrepreneurial education with a CR score of 17.937. This is due to the fact that culture in university and community environment makes students have to learn about entrepreneurship. With the support of culture, students are more confident in 
learning entrepreneurship material. There are examples of young entrepreneurs who successfully presented at universities as practitioners. The result of this study is indifferent of the prior studies by Ao and Liu (2014), Holmgren and From (2005), Jack and Anderson (1999), Mueller and Thomas (2001), Jabeen et al. (2017), and Jack and Anderson (1999).

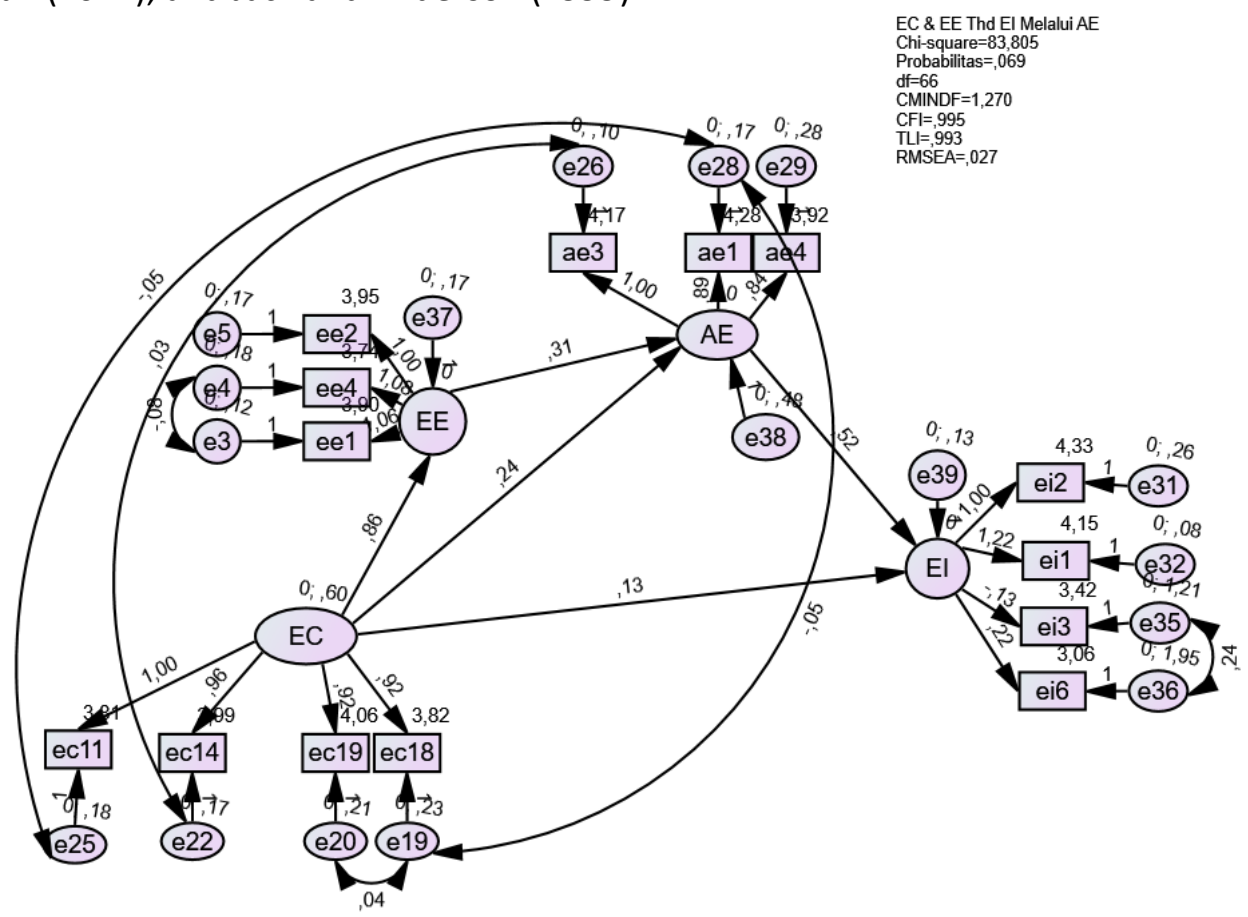

Figure 2. The structural equation model estimation

Source: own elaboration.

Moreover, based on the previous analysis, we found a significant effect between entrepreneurial culture and entrepreneurial attitude, with a CR score of 2.823 and $p$-value of 0.005 . This implies that entrepreneurial culture within the student environment could form attitudes towards entrepreneurship. Culture is important in every dimension of entrepreneurship because it determines individual attitudes towards entrepreneurship initiation. This finding suggests that culture is the most effective constant for entrepreneurs. A good cultural value also leads to intentions of becoming an entrepreneur. The result of this study is in agreement with prior research by Aloulou (2016), Holmgren and From (2005), Şeşen and Pruett (2014).

The third hypothesis $(\mathrm{H} 3)$ argues that there is a direct positive impact of entrepreneurial education on entrepreneurial attitude. This study confirmed previous research by Fayolle and Gailly (2015), Florin and Rossiter (2015), Potishuk and Kratzer (2017), Schwarz et al. (2009), Şeşen and Pruett (2014), and Zhang and Espinoza (1998). Students who enrolled in this study considered that the results of entrepreneurial learning could form attitudes able to foster their entrepreneurial spirit. Due to its moderate CR score, the entrepreneurship material from this time is considered in need of improvement because of the limited lecture time, which only gives three credit semesters in one semester during the study period. Entrepreneurship curriculum on campuses has more theoretical material than practical exercises.

Furthermore, this study also showed the significant effect of entrepreneurial attitude on entrepreneurial intention. In this study, students who participated stated that entrepreneurial intentions can be formed if students consider that a career as an entrepreneur is exciting. Many opportunities can be obtained through entrepreneurship. The need for seriousness in conducting an entrepreneurial career happens through exploring all existing business processes. These students can also create business ventures in the future. This implies that high motivation and intention toward entrepreneurship can drive students' success in running a business. The finding supports prior research conducted by Ayalew and Zeleke (2018), Fayolle and Gailly (2015), Krueger et al. (2000), Potishuk and Kratzer (2017), Schwarz et al. (2009), and Zampetakis et al. (2008). 
The next hypothesis is that there is a positive direct impact on entrepreneurial culture and entrepreneurial intention. The study found that H5 was significant with a CR score of 3.584, which implies that entrepreneurial culture positively affects entrepreneurial intention. In this study, there is evidence from some students who believe that entrepreneurial culture in an institution was important in supporting their confidence gain. Noticeable students also began to open to changes in teaching and learning models. Some students became open to an organization's vision of the future. Institutions began to increase mutual trust and respect among students. Support from the academic community during a crisis is what students who start businesses need. Nevertheless, this finding confirmed the results of preliminary studies by Ao and Liu (2014), Bogatyreva et al. (2019), Şeşen and Pruett (2014), Solesvik et al. (2014), Gerba (2012).

The sixth and seventh hypothesis sought to understand the mediating role of entrepreneurial attitude. Based on statistical calculation, the variable of entrepreneurial attitude was successful in mediating entrepreneurial culture towards entrepreneurial intention. The results of this work support the results of Bogatyreva et al. (2019), Sajjad and Dad (2010), Solesvik et al. (2014), Ayalew and Zeleke (2018), DíazGarcía and Jiménez-Moreno (2010), Mahendra et al. (2017), Shao-Hui et al. (2011). This is evidenced by the attitude towards good entrepreneurship from students who intend to become better entrepreneurs with the support of the entrepreneurial culture of their environment. This finding is reasonable because the entrepreneurial culture built at universities will form an entrepreneurial attitude and a strong intention to become an entrepreneur. The Indonesian government, through the Ministry of Higher Education, has instructed all universities - both public and private - to foster entrepreneurial culture in order to increase the number of entrepreneurs born from the world of higher education.

The study also confirmed that entrepreneurial attitude can mediate the relationship between entrepreneurship education and entrepreneurial intention. This agrees with the numerous findings by Hussain and Norashidah (2015), Kalyoncuoğlu et al. (2017), Piperopoulos and Dimov (2015), Souitaris et al. (2007), Tiwari et al. (2017), Ayalew and Zeleke (2018), Díaz-García and Jiménez-Moreno (2010). Thus, our study implies that entrepreneurship education plays a crucial role in promoting students' entrepreneurial intention. Hence, universities should explore models of entrepreneurship education at all levels of education, e.g. by providing more practical courses instead of theoretical ones and by elaborating existing curricula to follow the rapid global changes.

\section{CONCLUSIONS}

This study aimed to evaluate the influence of entrepreneurial education, entrepreneurial culture, and entrepreneurial attitude on entrepreneurial intention. The above analyses allow us to surmise that entrepreneurship education positively influences entrepreneurial attitude. Similarly, entrepreneurial culture impacts entrepreneurial attitude, entrepreneurship education, and entrepreneurial intention. Moreover, entrepreneurial attitude affects the intention to become an entrepreneur. Furthermore, entrepreneurial attitude can explain both the connectivity between entrepreneurship education and entrepreneurial intention - or entrepreneurial culture - and students' intention to become entrepreneurs.

Thus, the study confirmed that entrepreneurship and cultural education play an essential role in the intention to become an entrepreneur. Therefore, universities not only update and revitalize entrepreneurship curricula but also create a strong entrepreneurial culture. This entrepreneurial culture can be adapted to the characteristics of each campus. An entrepreneurial culture can be built e.g. by holding meetings of young entrepreneurs from both campus and outside, seminars, conferences, festivals, and fairs; and by using printed media in the form of brochures, banners, and magazines.

The main limitation of our study lies in the fact that the data was gathered solely from several universities in Malang of Indonesia, so the results cannot be generalized to represent real conditions in all universities in Indonesia. Future scholars should involve all universities in Indonesia so as to provide results that could be generalized. Moreover, this study only tested three independent variables and one dependent variable. Future studies should investigate other dominant factors that influence students' intention to begin a business activity. Research using the mixed method is very suitable to develop this study in the future. 


\section{REFERENCES}

Adekiya, A.A., \& Ibrahim, F. (2016). Entrepreneurship intention among students. The antecedent role of culture and entrepreneurship training and development. International Journal of Management Education, 14(2), 116-132. https://doi.org/10.1016/j.ijme.2016.03.001

Ahlstrom, D., \& Bruton, G.D. (2002). An institutional perspective on the role of culture in shaping strategic actions by technology-focused entrepreneurial firms in China. Entrepreneurship Theory and Practice, 26(4), 53-68.

Ahmed, T., Chandran, V.G.R., Klobas, J.E., Ahmed, T., Chandran, V.G.R., \& Demographic, J.E.K. (2017). Demographic differences in learner response to entrepreneurial education programmes in Pakistan. Educational Studies, 43(4), 464-483. https://doi.org/10.1080/03055698.2017.1293506

Ajzen, I. (1991). The theory of planned behavior. Organizational Behavior and Human Decision Processes, 211, 179-211. https://doi.org/10.1016/0749-5978(91)90020-T

Fishbein, M., \& Ajzen, I. (1975). Belief, Attitude, Intention, and Behavior: An Introduction to Theory and Research. Reading, MA: Addison-Wesley.

Akcay, O., Sun, Q., Almerico, G.M., Lafferty, B.A., Matulich, E., Liu, M.X., Tolba, A., Mourad, M., Wu, H., Shao, B., Thomas, D.C., Au, K., Valentine, S.R., Rittenburg, T.L., Pothukuchi, V., Damanpour, F., Choi, J., Chen, C.C., Park, S.H., ... Lerner, R.E. (2014). Political and economic impacts on Chinese students' return. Journal of International Business Studies, 33(2), 1-6. https://doi.org/10.1057/palgrave.jibs.8400377.

Allen, P.J., \& Bennett, K. (2010). PASW statistics by SPSS: A practical guide. Version 18.0: Cengage Learning.

Aloulou, W.J. (2016). Predicting entrepreneurial intentions of final year Saudi university business students by applying the theory of planned behavior. Journal of Small Business and Enterprise Development, 23(4). https://doi.org/10.1108/JSBED-02-2016-0028

Ao, J., \& Liu, Z. (2014). What impact entrepreneurial intention? Cultural, environmental, and educational factors. Journal of Management Analytics, 1(3), 224-239. https://doi.org/10.1080/23270012.2014.994232

Acs, Z., Szerb, L., \& Autio, E. (2017) Introduction to the Global Entrepreneurship Index. In: Global Entrepreneurship and Development Index 2016. SpringerBriefs in Economics. Springer, Cham. https://doi.org/10.1007/978-3-319-63844-7_1

Ayalew, M.M., \& Zeleke, S.A. (2018). Modeling the impact of entrepreneurial attitude on self-employment intention among engineering students in Ethiopia. Journal of Innovation and Entrepreneurship, 7(1), 8. https://doi.org/10.1186/s13731-018-0088-1

Bogatyreva, K., Edelman, L.F., Manolova, T.S., Osiyevskyy, O., \& Shirokova, G. (2019). When do entrepreneurial intentions lead to actions? The role of national culture. Journal of Business Research, 96, 306-321. https://doi.org/10.1016/j.jbusres.2018.11.034

Borasi, R., \& Finnigan, K. (2010). Entrepreneurial attitudes and behaviors that can help prepare successful changeagents in education. The New Educator, 6(1), 1-29. https://doi.org/10.1080/1547688X.2010.10399586

Botsaris, C., \& Vamvaka, V. (2016). Attitude Toward Entrepreneurship: Structure, Prediction from Behavioral Beliefs, and Relation to Entrepreneurial Intention. Journal of the Knowledge Economy, 7(2), 433-460. https://doi.org/10.1007/s13132-014-0227-2

Cheng, M.Y., Chan, W.S., \& Mahmood, A. (2009). The effectiveness of entrepreneurship education in Malaysia. Education + Training, 51(7), 555-566. https://doi.org/10.1108/00400910910992754

Collins, L., Hannon, P.D., \& Smith, A. (2004). Enacting entrepreneurial intent: The gaps between student needs and higher education capability. Education + Training, 46, 454-463. https://doi.org/10.1108/00400910410569579

Denanyoh, R., Adjei, K., \& Nyemekye, G.E. (2015). Factors that impact on entrepreneurial intention of tertiary students in Ghana. International Journal of Business and Social Research, 5(3), 19-29.

Díaz-García, M.C., \& Jiménez-Moreno, J. (2010). Entrepreneurial intention: The role of gender. International Entrepreneurship and Management Journal, 6(3), 261-283. https://doi.org/10.1007/s11365-008-0103-2

Dickson, P.H., Peachtree, W., \& Nw, S. (2004). Entrepreneurial orientation: The role of institutional environment and firm attributes in shaping innovation and proactiveness. Paper Presented at the Strategic Management Society Conference, 404, 1-25. 
Diegoli, R.B., Gutierrez, H.S.M., \& Los Salmones, M.D.M. G.De. (2018). Teachers as entrepreneurial role models: The impact of a teacher's entrepreneurial experience and student learning styles in entrepreneurial intentions. Journal of Entrepreneurship Education, 21(1), 1-11.

Emrah, T., K.C, A., \& Ibrahim, O.O. (2013). The Influence of Demographic Factors on Entrepreneurial Intention Among Undergraduate Students as a Career Choice. American International Journal of Contemporary Research, 3(12), 22-31.

Engle, R.L., Dimitriadi, N., Gavidia, J.V., Schlaegel, C., Delanoe, S., Alvarado, I., He, X., Buame, S., \& Wolff, B. (2010). Entrepreneurial intent: A twelve-country evaluation of Ajzen's model of planned behavior. Team Performance Management, 16(1-2), 35-57. https://doi.org/10.1108/13552551011020063

Esmi, K., Marzoughi, R., \& Torkzadeh, J. (2015). Teaching learning methods of an entrepreneurship curriculum. Journal of Advances in Medical Education \& Professionalism, 3(4), 172-177.

Fayolle, A., \& Gailly, B. (2015). The impact of entrepreneurship education on entrepreneurial attitudes and intention: Hysteresis and persistence. Journal of Small Business Management, 53(1), 75-93. https://doi.org/10.1111/jsbm.12065

Fernandes, T., \& Proença, J. (2014). Reassessing Relationships in Consumer Markets: Emotion, Cognition, and Consumer Relationship Intention Markets: Emotion, Cognition, and Consumer. Journal of Relationship Marketing, 37-41. https://doi.org/10.1080/15332667.2013.763719

Fernández-Pérez, V., Montes-Merino, A., Rodríguez-Ariza, L., \& Galicia, P.E.A. (2019). Emotional competencies and cognitive antecedents in shaping student's entrepreneurial intention: the moderating role of entrepreneurship education. International Entrepreneurship and Management Journal, 15(1). https://doi.org/10.1007/s11365-017-0438-7

Fernandez, D.R., Carlson, D.S., Stepina, L.P., \& Nicholson, J.D. (1997). Hofstede's country classification 25 years later. Journal of Social Psychology, 137(1), 43-54. https://doi.org/10.1080/00224549709595412

Fini, R., Grimaldi, R., Marzocchi, G.L., \& Sobrero, M. (2012). The determinants of corporate entrepreneurial intention within small and newly established firms. Entrepreneurship: Theory and Practice, 36(2), 387-414. https://doi.org/10.1111/j.1540-6520.2010.00411.x

Florin, J., \& Rossiter, N. (2015). Fostering entrepreneurial drive in business education: an attitudinal approach. Journal of Management Education, 31(1), 17-42. https://doi.org/10.1177/1052562905282023

Gerba, D.T. (2012). Impact of entrepreneurship education on entrepreneurial intentions of business and engineering students in Ethiopia. African Journal of Economic and Management Studies, 3(2), 258-277. https://doi.org/10.1108/20400701211265036

Hair, J.F., Black, W.C., Babin, B.J., Anderson, R.E., \& Tatham, R.L. (1998). Multivariate data analysis (Vol. 5, No. 3, pp. 207-219). Upper Saddle River, NJ: Prentice hall.

Hair, J.F., Howard, M.C., \& Nitzl, C. (2020). Assessing measurement model quality in PLS-SEM using con firmatory composite analysis. Journal of Business Research, 109, 101-110. https://doi.org/10.1016/j.jbusres.2019.11.069

Hayton, J.C., \& Cacciotti, G. (2013). Is there an entrepreneurial culture? A review of empirical research. Entrepreneurship \& Regional Development, 25(9-10), 708-731. https://doi.org/10.1080/08985626.2013.862962

Hayton, J.C., George, G., \& Zahra, S.A. (2002). National culture and entrepreneurship: A review of behavioral research. Entrepreneurship Theory and Practice, 26(4), 33-52. https://doi.org/10.1177/104225870202600403

Hofstede, G. (2001). Culture's recent consequences: Using dimension scores in theory and research. International Journal of Cross Cultural Management, 1(1), 11-17. https://doi.org/10.1177\%2F147059580111002

Holmgren, C., \& From, J. (2005). Taylorism of the Mind: Entrepreneurship education from a perspective of educational research. European Educational Research Journal, 4(4), 382-390. https://doi.org/10.2304/eerj.2005.4.4.4

House, R., Javidan, M., Hanges, P., \& Dorfman, P. (2002). Understanding cultures and implicit leadership theories across the globe: an introduction to project GLOBE. Journal of World Business, 37, 3-10. https://doi.org/10.1016/S1090-9516(01)00069-4

Hu, L.T., \& Bentler, P.M. (1999). Cutoff criteria for fit indexes in covariance structure analysis: Conventional criteria versus new alternatives. Structural Equation Modeling, 6(1), 1-55. https://doi.org/10.1080/10705519909540118

Hussain, A., \& Norashidah, D. (2015). Impact of Entrepreneurial Education on Entrepreneurial Intentions of Pakistani Students. Journal of Entrepreneurship and Business Innovation, 2(1), 43. https://doi.org/10.5296/jebi.v2i1.7534 
lakovleva, M., \& Solesvik, A.T. (2013). Entrepreneurship policy and the role of government and financial institutions in supporting women entrepreneurs in transition economies - the case of Russia and Ukraine. Journal of Small Business and Enterprise Development, 20(2), 314-340. https://doi.org/10.1108/14626001311326752

Ibrahim, N.A., \& Mas'ud, A. (2016). Moderating role of entrepreneurial orientation on the relationship between entrepreneurial skills, environmental factors and entrepreneurial intention: A PLS approach. Management Science Letters, 6, 225-236. https://doi.org/10.5267/j.msl.2016.1.005

Ireland, R.D., Covin, J.G., \& Kuratko, D.F. (2009). Conceptualizing Corporate Entrepreneurship Strategy. Entrepreneurship Theory \& Practice, 979, 19-46. https://doi.org/10.1111\%2Fj.1540-6520.2008.00279.x

Jabeen, F., Faisal, M.N., \& Katsioloudes, M.I. (2017). Entrepreneurial mindset and the role of universities as strategic drivers of entrepreneurship: Evidence from the United Arab Emirates. Journal of Small Business and Enterprise Development, 24(1), 136-157. https://doi.org/10.1108/JSBED-07-2016-0117

Jack, S.L., \& Anderson, A.R. (1999). Entrepreneurship education within the enterprise culture: Producing reflective practitioners. International Journal of Entrepreneurial Behaviour \& Research, 5(3), 110-125. https://doi.org/10.1108/13552559910284074

Jena, R.K. (2020). Measuring the Impact of Business Management Student's Attitude towards Entrepreneurship Education on Entrepreneurial Intention. Computers in Human Behavior, 107, 106275. https://doi.org/10.1016/j.chb.2020.106275

Kalyoncuoğlu, S., Aydıntan, B., \& Göksel, A. (2017). The Effect of Entrepreneurship Education on Entrepreneurial Intention: An Experimental Study on Undergraduate Business Students. Journal of Management Research, 9(3), 72. https://doi.org/10.5296/jmr.v9i3.11282

Karayiannis, A.D. (1993). Entrepreneurial Pluralism and Cultural Diversity Anastassios. University of Piraeus.

Karimi, S., Biemans, H.J.A., Lans, T., Chizari, M., \& Mulder, M. (2016). The Impact of entrepreneurship education: A study of Iranian students' entrepreneurial intentions and opportunity identification. Journal of Small Business Management, 54(1), 187-209. https://doi.org/10.1111/jsbm.12137

Kibler, E. (2013). Formation of entrepreneurial intentions in a regional context. Entrepreneurship \& Regional Development, 25(3-4), 293-323. https://doi.org/10.1080/08985626.2012.721008

Kirkwood, J., Dwyer, K., \& Gray, B. (2014). Students' reflections on the value of an entrepreneurship education. International Journal of Management Education, 12(3), 307-316. https://doi.org/10.1016/j.ijme.2014.07.005

Kreiser, P.M., Marino, L.D., Dickson, P., \& Weaver, K.M. (2010). Cultural influences on entrepreneurial orientation: The impact of national culture on risk taking and proactiveness in SMEs. Entrepreneurship theory and practice, 34(5), 959-984. https://doi.org/10.1111/j.1540-6520.2010.00396.x

Krueger, N.F.J., Reilly, M.D., \& Carsrud, A.L. (2000). Competing Models of Entrepreneurial Intentions. Journal of Business Venturing, 15(98), 411-432. https://doi.org/10.1016/S0883-9026(98)00033-0

Kusmintarti, A., Thoyib, A., Maskie G., \& Ashar, K. (2014). Journal of entrepreneurship education. Journal of Entrepreneurship Education, 17(1), 1-2.

Küttim, M., Kallaste, M., Venesaar, U., \& Kiis, A. (2014). Entrepreneurship Education at University Level and Students' Entrepreneurial Intentions. Procedia - Social and Behavioral Sciences, 110, 658-668. https://doi.org/10.1016/j.sbspro.2013.12.910

Linan, F., \& Chen, Y. (2009). Development and cross-cultural application of a specific instrument to measure entrepreneurial intentions. Entrepreneurship Theory and Practice, 33(3), 593. https://doi.org/10.1111/j.15406520.2009.00318.x

MacKenzie, S.B., Podsakoff, P.M., \& Podsakoff, N.P. (2011). Construct measurement and validation procedures in MIS and behavioral research: Integrating new and existing techniques. MIS Quarterly, 35(2), 293-334. https://doi.org/10.5555/2017507.2017510

Mahendra, A.M., Djatmika, E.T., \& Hermawan, A. (2017). The effect of entrepreneurship education on entrepreneurial intention mediated by motivation and attitude among management students, State University of Malang, Indonesia. International Education Studies, 10(9), 61. https://doi.org/10.5539/ies.v10n9p61

Malhotra, N.K. (2010). Marketing research an applied orientation. Pearson Education Inc.

Mathisen, J., \& Arnulf, J.K. (2013). Competing mindsets in entrepreneurship: The cost of doubt. The International Journal of Management Education, 11(3), 132-141. https://doi.org/10.1016/j.ijme.2013.03.003 
Matlay, H., Rae, D., \& Piperopoulos, P. (2012). Could higher education programmes, culture and structure stifle the entrepreneurial intentions of students?. Journal of Small Business and Enterprise Development, 19(3), 461-483. https://doi.org/10.1108/14626001211250162

Mueller, S.L., \& Thomas, A.S. (2001). Culture and entrepreneurial potential: A nine country study of locus of control and innovativeness. Journal of Business Venturing, 16(1), 51-75. https://doi.org/10.1016/S0883-9026 (99) 00039-7

Nagib, L., \& Ngadi, N.F.N. (2008). Challenges of Unemployment in Indonesia: Trends, Issues and Policies. Jurnal Kependudukan Indonesia, 3(2), 1-28.

Oosterbeek, H., van Praag, M., \& ljsselstein, A. (2010). The impact of entrepreneurship education on entrepreneurship skills and motivation. European Economic Review, 54(3), 442-454. https://doi.org/10.1016/j.euroecorev.2009.08.002

Piperopoulos, P., \& Dimov, D. (2015). Burst Bubbles or Build Steam? Entrepreneurship Education, Entrepreneurial Self-Efficacy, and Entrepreneurial Intentions. Journal of Small Business Management, 53(4), 970-985. https://doi.org/10.1111/jsbm.12116

Porter, M. (1990). The comparative advantage of nations. New York: Free Press.

Pruett, M., Shinnar, R., Toney, B., Carolina, N., Llopis, F., \& Fox, J. (2008). Explaining entrepreneurial intentions of university students: a cross-cultural study. International Journal of Entrepreneurial Behaviour \& Research, 15(6), 571-594. https://doi.org/10.1108/13552550910995443

Reynolds, P., Storey, D.J., \& Westhead, P. (2007). Cross-national comparisons of the variation in new firm formation rates. Regional Studies, 41(S1), S123-S136. https://doi.org/10.1080/00343400701232280

Sajjad, S.I., \& Dad, A.N. (2010). Impact of Culture on Entrepreneur Intention. Information Management and Business Review, 4(1), 30-34. https://doi.org/10.22610/imbr.v4i1.960

Schermelleh-Engel, K., Moosbrugger, H., \& Müller, H. (2003). Evaluating the fit of structural equation models: Tests of significance and descriptive goodness-of-fit measures. Methods of Psychological Research Online, 8(2), 23-74.

Schlaegel, C., \& Koenig, M. (2014). Determinants of entrepreneurial intent: a meta - analytic test and integration of competing models. Entrepreneurship Theory and Practice, 38(2), 291-332. https://doi.org/10.1111/etap.12087

Schwarz, E.J., Wdowiak, M.A., Almer-Jarz, D.A., \& Breitenecker, R.J. (2009). The effects of attitudes and perceived environment conditions on students' entrepreneurial intent: An Austrian perspective. Education and Training, 51(4), 272-291. https://doi.org/10.1108/00400910910964566

Sekaran, U., \& Bougie, R. (2009). Research methods for business. The United Kingdom: Wiley.

Şeşen, H., \& Pruett, M. (2014). The impact of education, economy and culture on entrepreneurial motives, barriers and intentions: A comparative study of the United States and Turkey. Journal of Entrepreneurship, 23(2), 231-261. https://doi.org/10.1177/0971355714535309

Shao-Hui, L., Ping, L., \& Peng-Peng, F. (2011). Mediation and moderated mediation in the relationship among entrepreneurial self-efficacy, entrepreneurial intention, entrepreneurial attitude and role models. International Conference on Management Science and Engineering - Annual Conference Proceedings, 129-134. https://doi.org/10.1109/ICMSE.2011.6069954

Solesvik, M., Westhead, P., \& Matlay, H. (2014). Cultural factors and entrepreneurial intention: The role of entrepreneurship education. Education and Training, 56, 680-696. https://doi.org/10.1108/ET-07-2014-0075

Souitaris, V., Zerbinati, S., \& Al-Laham, A. (2007). Do entrepreneurship programmes raise entrepreneurial intention of science and engineering students? The effect of learning, inspiration and resources. Journal of Business Venturing, 22(4). https://doi.org/10.1016/j.jbusvent.2006.05.002

Syuhada, A.A., \& Gambett, W. (2013). Online Marketplace for Indonesian Micro Small and Medium Enterprises based on Social Media. Procedia Technology, 11, 446-454. https://doi.org/10.1016/j.protcy.2013.12.214

Tabachnick, B.G., \& Fidell, L.S. (2007). Using multivariate statistics (5 ed.). Boston Pearson/Allyn \& Bacon.

Tiwari, P., Bhat, A.K., \& Tikoria, J. (2017). Relationship between entrepreneurship education and entrepreneurial intentions: A validation study. In Entrepreneurship Education: Experiments with Curriculum, Pedagogy and Target Groups. https://doi.org/10.1007/978-981-10-3319-3_9

Triandis, H.C. (1982). Review of culture's consequences: International differences in work-related values. Human Organization, 41(1), 86-90. 
Udayanan, P. (2019). The Role of Self-Efficacy and Entrepreneurial Self-Efficacy on the Entrepreneurial Intentions of Graduate Students: A Study among Omani Graduates. Entrepreneurial Business and Economics Review, 7(4), 7-20. https://doi.org/10.15678/EBER.2019.070401

Vargas-Hernández, J.G., Noruzi, M.R., \& Sariolghalam, N. (2010). An Exploration of the Affects of Islamic Culture on Entrepreneurial Behaviors in Muslim Countries. Asian Social Science, 6(5), 120-127. https://doi.org/10.5539/ass.v6n5p120

Wach, K., \& Wojciechowski, L. (2016). Entrepreneurial intentions of students in Poland in the view of Ajzen's theory of planned behaviour. Entrepreneurial Business and Economics Review, 4(1), 83-94. https://doi.org/10.15678/EBER.2016.040106

Wibowo, A., Saptono, A., \& Suparno (2018). Does teachers' creativity impact on vocational students' entrepreneurial intention?. Journal of Entrepreneurship Education, 21(3), 1-12.

Yan, Z. (2014). Predicting teachers' intentions to implement school-based assessment using the theory of planned behaviour. Educational Research and Evaluation: An International Journal on Theory and Practice, 20(1), 83-97. https://doi.org/10.1080/13803611.2013.877394

Zahra, S.A., \& George, G. (2002). Absorptive Capacity: A review, reconceptualization, and extension. Academy of Management Review, 27(2), 185-203.

Zahra, S.A., Jennings, D.F., \& Kuratko, D.F. (1999). The antecedents and entrepreneurship: The state of the field. Entrepreneurship Theory and Practice, 24(2), 45-3.

Zampetakis, L.A., Bouranta, N., \& Dewett, T. (2008). On the relationship between emotional intelligence and entrepreneurial attitudes and intentions. International Journal of Entrepreneurial Behaviour \& Research, 15(6), 595-618. https://doi.org/10.1108/13552550910995452

Zampetakis, L.A., Gotsi, M., Andriopoulos, C., \& Moustakis, V. (2011). Creativity and Entrepreneurial Intention in Young People. The International Journal of Entrepreneurship and Innovation, 12(3), 189-199. https://doi.org/10.5367/ijei.2011.0037

Zamrudi, Z., \& Yulianti, F. (2020). Sculpting Factors of Entrepreneurship Among University Students in Indonesia. Entrepreneurial Business and Economic Review, 8(1), 22-49. https://doi.org.10.15678/EBER.2020.080102

Zhang, Y., \& Espinoza, S. (1998). Relationships among computer self-efficacy, attitudes toward computers, and desirability of learning computing skills. Journal of Research on Computing in Education, 30(4), 420-436. https://doi.org/10.1080/08886504.1998.10782236 


\section{Authors}

The contribution of co-authors is as follows:

Ludi Wishnu Wardana (25\%) and Agus Wibowo (15\%) devised the project, the main conceptual ideas, and proof outlines. Thusy Tiara Saraswati (15\%) and Fitriana (15\%) provided the technical details and performed the research. Bagus Shandy Narmaditya (15\%) and Riza Indriani (15\%) wrote the entire paper, later translated and proofread by Bagus Shandy Narmaditya.

\section{Ludi Wishnu Wardana}

Associate Professor of entrepreneurship education at the Faculty of Economics of the Universitas Negeri Malang, Indonesia. He is interested in entrepreneurship and entrepreneurship education. He contributes as editor and reviewer in various journals.

Correspondence to: Dr. Ludi Wishnu Wardana, Faculty of Economics, Universitas Negeri Malang, Jalan Semarang 5 Malang 65145, Indonesia e-mail: ludi.wishnu.fe@um.ac.id

ORCID (1) http://orcid.org/0000-0003-4213-5213

\section{Bagus Shandy Narmaditya}

Lecturer at the Faculty of Economics of the Universitas Negeri Malang, Indonesia. He graduated in the Economic Education Program at the Universitas Negeri Malang. His research focuses on economic education, entrepreneurship education, and economic welfare. He participated at the GSE summer school at the Universitat Pompeu Fabra, Barcelona, Spain. Moreover, he also actively participated in international conferences in Indonesia, Thailand, Vietnam, Hongkong, and Japan.

Correspondence to: Bagus Shandy Narmaditya, Faculty of Economics, Universitas Negeri Malang, Jalan Semarang 5 Malang 65145, Indonesia e-mail: bagus.shandy.fe@um.ac.id

ORCID 다 http://orcid.org/0000-0002-4019-8723

\section{Agus Wibowo}

Assistant Professor of entrepreneurship at the Faculty of Economics of Universitas Negeri Jakarta, Indonesia. $\mathrm{He}$ is a doctoral candidate in Economic Education, Universitas Negeri Malang. He is an editor and reviewer in several social sciences journal and focuses on entrepreneurship education and economic education.

Correspondence to: Agus Wibowo, Faculty of Economics, Universitas Negeri Jakarta, Jalan Rawamangun Muka, Jakarta Timur, 13220, Indonesia, e-mail: agus-wibowo@unj.ac.id

ORCID (1) http://orcid.org/0000-0003-0051-1743

\section{Fitriana}

Students at Faculty of Economics Universitas Negeri Malang, Indonesia. She concerned in assisting of the research in the field of entrepreneurship and entrepreneurship education.

Correspondence to: Fitirana, Faculty of Economics, Universitas Negeri Malang, Jalan Semarang 5 Malang 65145, Indonesia e-mail: fitriana.12@gmail.com

ORCID $₫$ http://orcid.org/0000-0002-1084-0754

\section{Thusy Tiara Saraswati}

Student at the Faculty of Economics of Universitas Negeri Malang, Indonesia. She assists in research in the field of entrepreneurship and entrepreneurship education.

Correspondence to: Thusy Tiara Saraswati, Faculty of Economics, Universitas Negeri Malang, Jalan Semarang 5 Malang 65145, Indonesia e-mail: thusytiara@gmail.com

ORCID (1) http://orcid.org/0000-0003-4076-4585

Riza Indriani

Lecturer at the Faculty of Economics of Universitas Negeri Medan, Indonesia. She focuses on the field of entrepreneurship and entrepreneurship education.

Correspondence to: Riza Indriani, Faculty of Economics, Universitas Negeri Medan, Jl. William Iskandar Ps. V, Kenangan Baru, Kabupaten Deli Serdang, Sumatera Utara 20221, Indonesia e-mail: rizaindriani@unimed.ac.id ORCID (1) http://orcid.org/0000-0003-0833-9669 


\section{Acknowledgements and Financial Disclosure}

The authors would like to thank the anonymous referees for their valuable comments, which allowed to increase the value of this article.

\section{Conflict of Interest}

The authors declare that the research was conducted in the absence of any commercial or financial relationships that could be construed as a potential conflict of interest.

\section{Copyright and License}

This article is published under the terms of the Creative Commons

Attribution - NoDerivs (CC BY-ND 4.0) License

http://creativecommons.org/licenses/by-nd/4.0/ 